Int. J. Electrochem. Sci., 12 (2017) 2973 - 2986

\title{
Effect of Heat Treatments on the Electrochemical Behavior of 304L Stainless Steel in Nitric Acid
}

\author{
Lingzhen Kong, Kuisheng Wang ${ }^{*}$, Yupeng Zhan, Yu Zhang \\ College of Mechanical and Electrical Engineering, Beijing University of Chemical Technology, \\ Beijing 100029, P.R. China \\ *E-mail: kuishengw@163.com
}

doi: $10.20964 / 2017.04 .50$

Received: 19 December 2016 / Accepted: 18 February 2017 / Published: 12 March 2017

\begin{abstract}
In this study, the intergranular corrosion behavior of 304L stainless steel (SS) after heating at different temperatures and times was investigated by using the double loop electrochemical potentiokinetic reactivation (DL-EPR), the potentiodynamic polarization electrochemical and the electrochemical impedance spectroscopy (EIS) methods. It was found that there was no significant difference in the potentiodynamic polarization curves of the specimens after different heat treatments. However, the corrosion resistance of specimens could be clearly distinguished by EIS. Between 650 to $750^{\circ} \mathrm{C}$, the degree of sensitisation (DOS) had a maximum value and the decrease in $\mathrm{R}_{\mathrm{ct}}$ was more prominent for the specimens aged at 650 and $750^{\circ} \mathrm{C}$. Heat treatments conducted in the range of $650-750^{\circ} \mathrm{C}$, even a brief heating time, caused a serious decline in the corrosion resistance of $304 \mathrm{~L} \mathrm{SS}$. The $\mathrm{R}_{\mathrm{ct}}$-values of the specimens aged at 650 and $750^{\circ} \mathrm{C}$ decreased with the increase of the heating time. However, the $\mathrm{R}_{\mathrm{ct}}$-values of the specimens aged at $850^{\circ} \mathrm{C}$ increased with the increase of the heating time.
\end{abstract}

Keywords: Stainless steel; Intergranular corrosion; DL-EPR; EIS; Nitric acid

\section{$\underline{\text { FULL TEXT }}$}

(C) 2017 The Authors. Published by ESG (www.electrochemsci.org). This article is an open access article distributed under the terms and conditions of the Creative Commons Attribution license (http://creativecommons.org/licenses/by/4.0/). 